\title{
Pendampingan Pelaporan SPT Tahunan Berbasis E-filing Bagi Pedagang Kelontong di tengah Wabah Covid-19
}

\author{
Ni Ketut Sriwinarti ${ }^{1}$, Dewa Ayu Oki A. ${ }^{2}$, R. Ayu Ida Aryani ${ }^{3}$, \\ Baiq Adrian Ulfa ${ }^{4}$, Ikang Murapi ${ }^{5}$ \\ sriwinarti@stmikbumigora.ac.id ${ }^{1}$ \\ 1,2,3,4,5 Universitas Bumigora
}

\author{
Article History: \\ Received: \\ Revised: \\ Accepted:
}

Keywords: Covid-19, e-filing, e-form, e-SPT

\begin{abstract}
Government appeals to stay at home and restrictions on the delivery of public services do make people less comfortable in receiving public services, but this is a policy currently taken by the government is an effort to limit or stop the spread of Corona Virus. based on the instructions given, DJP (Direktorat Jenderal Pajak) then stop reporting directly and lead to the use of e-filing and extend the tax reporting period that should end on 31 March 2020 to 30 April 2020. Termination is what later became a problem experienced by taxpayers, especially the grocery traders in Gerung Market, Gerung District, West Lombok Regency, where the average trader was very unfamiliar with the use of electronics, especially the use of computers and the internet. By coordinating with an account representative, the servant provides assistance to traders who wish to report their annual tax return online while still paying attention to social distancing or maintaining a safe distance from participants. because of the adaptations made so that not all registered participants can be accompanied, namely only $50 \%$ of participants who successfully report online, $20 \%$ of participants are reported manually and the rest are still waiting for further policies.
\end{abstract}

\section{Pendahuluan}

E-filing merupakan salah satu aplikasi yang diluncurkan pemerintah untuk membantu para wajib pajak dalam melaporkan pajaknya secara online. E-filing pajak lahir dari penerapan sistem Modul Penerimaan Negara Generasi Kedua (MPN G2) yang mulai dijalankan pada tahun 2007. Dalam sistem ini, negara menggunakan surat elektronik serta pembayaran dengan billing sebagai bagian dari sistem transaksinya. Menurut situs resmi kementerian keuangan, sistem ini berlaku baik untuk penerimaan negara yang berbentuk pajak maupun bukan pajak. Direktorat Jenderal Pajak adalah salah satu pihak penerima tagihan resmi (biller) di kementerian keuangan. Pemerintah kemudian membuat situs khusus untuk mendukung e-Filing dan e-Billing yakni sse.pajak dan efiling.pajak. Akan tetapi, situs-situs ini memiliki sistem yang terpisah dari situs resmi DJP (Direktorat Jendral Pajak). Pada tahun 2014, DJP menyatukan semua layanan pelaporan dan pembayaran pajak di bawah satu sistem. DJP juga membuat situs DJP Online (djponline.pajak.go.id) sebagai pusat pelayanan SPT elektronik (onlinepajak, 2018). 


\section{ADMA}

Gurnal Pengabdian dan Pemberdayaan Masyarakat
Vol.1, No.1, June 2020, pp. 19-26

Doi: $x x x x x x x x$

Proses penggunaan e-Filing dibedakan menjadi dua jenis yaitu e-Filing Dial Up dan e-Filing melalui ASP. e-Filing Dial Up adalah cara penyampaian SPT yang langsung terhubung dengan server di Direktorat Jenderal Pajak dengan melalui modem dari PC Wajib Pajak yang menyampaikan SPT nya, e-Filing Dial Up belum banyak digunakan dalam pelayanan kepada wajib pajak di KPP Pratama. Sedangkan e-Filing melalui ASP penggunaannya melalui beberapa proses di antaranya harus mendaftar ke ASP terlebih dahulu, kemudian menginstal aplikasi E-SPT, melakukan penyampaian SPT secara online lalu mencetak form induk SPT ke KPP.

Abdurrohman dkk (2015) juga mengungkapkan bahwa E-filing yang diluncurkan pemerintah merupakan salah satu program dalam modernisasi juga merupakan wujud e-government yang bertujuan memberikan kemudahan dalam penyampaian SPT tahunan pph pribadi. kemudahan yang diberikan diharapkan dapat meningkatkan kepatuhan wajib pajak orang pribadi. kemudahan yang diberikan diharapkan dapat meningkatkan kepatuhan wajib pajak orang pribadi. Namun meskipun DJP meluncurkan aplikasi e-Filing dan e-Billing di bawah satu sistem untuk pertama kalinya, DJP masih memberikan pilihan bagi masyarakat untuk melakukan sistem manual. Hal ini untuk mengantisipasi golongan masyarakat yang belum terbiasa dengan teknologi yang digunakan. penggunaan teknologi inilah yang kemudian menjadi kesulitan tersendiri oleh para wajib pajak khususnya para pedangan kecil dipasar, mereka kurang memiliki pengetahuan terhadap penggunaan teknologi khususnya komputer atau handphone android sehingga mereka lebih memilih untuk langsung datang ke kantor pajak untuk melaporkan spt tahunanya.

Di dalam pelaporan pajak pada tahun-tahun sebelumnya, penggunaan e-filing masih belum ditekankan oleh kantor pelayanan pajak (KPP) pratama dimana masyarakat masih diberikan kebebasan untuk ke kantor pajak demi melaporkan spt tahunannya, namun semenjak wabah virus covid-19 atau yang lebih dikenal dengan nama virus corona melanda Indonesia saat ini, maka demi mengantisipasi dan mengurangi jumlah penderita, pemerintah memberikan kebijakan membatasi aktivitas keluar rumah dan mengutamakan bekerja dari rumah (work from home), bahkan kegiatan beribadah pun dirumahkan. Dengan berlakunya work from home bagi pegawai-pegawai yang bergerak dalam pelayanan publik, menyebabkan pelayanan publik menjadi terhambat, karena pada akhirnya beberapa bidang pelayanan tidak dapat melayani masyarakat secara langsung. Akan tetapi, penyelenggara pelayanan publik kemudian membuat inovasi-inovasi dalam memberikan pelayanan agar palayanan tidak terhambat seperti memberikan pelayanan melalui sistem online.

Sistem online ini yang kemudian sedang digalakkan oleh beberapa penyelenggara pelayanan publik kepada masyarakat agar pelayanan publik tetap berjalan, seperti contoh beberapa penyelenggara yang melakukan pelayanan menggunakan sistem online yaitu PLN, yang menggunakan sistem online dalam pemberian pelayanan mulai dari penyambungan baru, perubahan daya sampai kepengaduan serta dalam pembayaran melalui ATM atau internet banking. Kemudian DJP (Direktorat Jenderal Pajak) juga menghentikan pelaporan secara langsung dan mengarahkan secara online serta memperpanjang masa pelaporan pajak yang seharusnya berakhir pada tanggal 31 Maret 2020 menjadi tanggal 30 April 2020 (Andhika, 2020).

Himbauan pemerintah untuk tetap berada di rumah dan pembatasan pemberian pelayanan publik ini memang membuat masyarakat menjadi kurang nyaman dalam menerima 


\section{ADMA}

Gurnal Pengabdian dan Pemberdayaan Masyarakat
Vol.1, No.1, June 2020, pp. 19-26

Doi: $x x x x x x x x$

pelayanan publik, tetapi ini merupakan kebijakan yang saat ini diambil pemerintah adalah upaya untuk membatasi atau menghentikan penyebaran Virus Corona. Dengan adanya pembatasan ini apakah kemudian hak-hak dari masyarakat dalam mendapatkan pelayanan publik menjadi berkurang? Itu merupakan pertanyaan lain yang kemudian mendasar dari sebagian besar masyarakat. karena kekurangan atau kesalahan kebijakan publik akan dapat diketahui setelah kebijakan publik tersebut dilaksanakan. Keberhasilan pelaksanaan kebijakan publik dapat dilihat dari dampak yang ditimbulkan sebagai hasil evaluasi atas pelaksanaan suatu kebijakan.

Salah satu kebijakan pelayanan publik yang kemudian kami soroti adalah pelaporan SPT tahunan orang pribadi yang ditekankan mengunakan e-filing. Penerapan kebijakan ini kemudian menjadi permasalahan baru yang dihadapi masyarakat khususnya bagi para pedagang kelontong di pasar kecamatan Gerung Kabupaten Lombok Barat, mereka mengalami kesulitan mengenai bagaimana pelaporan pajak menggunakan sistem ini, malah menurut mereka terasa asing, sedangkan untuk bertanya pada petugas pajak mengharuskan mereka untuk pergi ke kota Mataram dengan situasi saat ini Mataram berada pada zona merah (ditemukan kasus covid-19 pada satu atau lebih klaster dengan peningkatan yang cukup signifikan). mereka mengungkapkan keinginan untuk tidak melaporkan spt tahunannya pada tahun ini, namun adanya resiko akan sangsi denda memposisikan mereka pada kondisi yang dilematis.

Pelaporan spt tahunan yang dilakukan oleh para pedagang klontong di pasar gerung kabupaten lombok barat kebanyakkan adalah spt masa pph final pasal 4 ayat 2 yang mana rata-rata bersifat nihil karena sudah dibayarkan setiap bulannya. pph final pasal 4 ayat 2 merupakan pajak yang dikenakan pada wajib pajak badan maupun wajib pajak pribadi atas beberapa jenis penghasilan yang mereka dapatkan dan pemotongan pajaknya bersifat final. Tarif PPh Pasal 4 Ayat 2 ini berbeda-beda untuk setiap jenis penghasilannya. Misalnya untuk UMKM (Usaha Mikro Kecil Menengah), wiraswasta atau bisnis online dengan omzet usaha kurang dari Rp 4,8 miliar dalam 1 tahun pajak, maka tarif pajaknya adalah 0,5\% dari total omzet (peredaran bruto) penjualan dalam 1 bulan.

Di setiap kesempatan Account Representative (AR) atau orang yang melakukan pengawasan kepatuhan perpajakan Wajib pajak serta bertugas bimbingan/himbauan dan kunsultasi teknis perpajakan kepada wajib pajak, selalu mengatakan bahwasanya e-filling sangat mudah, tidak demikian yang dirasakan oleh para pedagang kelontong dipasar gerung, mereka merasa kebijakan ini sangan menyusahkan selain kebingungan akan menumenu yang ada, mereka juga mengalami kesusahan dalam sarana maupun prasarana yang tersedia. permasalahan-permasalahan inilah yang kemudian membuat kami memikirkan dan berupaya bagaimana cara mengatasi permasalahan yang dihadapi oleh para pedagang kelontong dipasar Gerung dengan melakukan pendampingan dalam proses pelaporan e-spt namun tetap memperhatikan social distancing atau menjaga jarak aman dengan mitra.

\section{Metode}

Ditengah masa pandemi virus corona (Covid-19) ini menuntut para akademisi beradaptasi untuk tetap menjalankan tri dharmanya khususnya pada point ketiga yaitu pengabdian kepada masyarakat. adaptasi ini dibutuhkan guna mambantu pemerintah dalam mencegah menyebarnya virus ini. namun demikian team pengabdi tetap berupaya agar adaptasi- 
adaptasi yang dilakukan tidak mengurangi esensial tujuan pengabdian ini dilakukan. berikut ini adalah beberapa tahapan yang dilakukan dalam proses pendampingan masyarakat khususnya para pedagang kelontong di pasar gerung kecamatan gerung kabupaten lombok barat:

1). Tahap Persiapan

a Menyediakan informasi secara jelas mengenai prosedur atau langkah-langkah pelaporan pajak berbasis on-line, untuk membuat materi ini, pengabdi menggunakan salah satu akun mitra yang bersedia berbagi informasinya untuk digunakan dengan syarat pengabdi bersedia untuk menjaga kerahasian dengan menyamarkan informasi didalamnya

b Menyediakan kebutuhan dilapangan, mengingat kondisi mitra yang tidak semuanya memiliki komputer/laptop

c Mendata para pedagang yang ingin didampingi, dimana peserta yang didampingi proses pelaporan pajaknya adalah para pedagang kelontong yang sudah memiliki NPWP dan berlokasi jualan di wilayah pasar gerung.

2). Tahap Pelaksanaan

Mengingat situasi yang tidak memungkinkan untuk melakukan pendampingan secara bersama, maka team pengabdi melakukan pendampingan dengan cara mengunjungi masing-masing pedagang baik dirumahnya maupun dipasar pada saat sudah siang hari.

3). Tahap Evaluasi

Melaksanakan evaluasi berkaitan tahap persiapan hingga pelaksanaan apakah terdapat permasalahan-permasalahan yang tidak diduga sehingga pada proses berikutnya dapat lebih dipersiapkan.

\section{Hasil dan Pembahasan}

\section{Dari E-filing ke E-form}

E-filing melalui website DJP mulai digunakan setelah berlakunya PER - 39/PJ/2011 yaitu pada tanggal 1 Februari 2012. e-Filing melalui website DJP ternyata hanya memberikan pelayanan berupa penyampaian dua jenis SPT, yaitu SPT Tahunan PPh Wajib Pajak Orang Pribadi formulir 1770S dan SPT Tahunan PPh Wajib Pajak Orang Pribadi formulir 1770SS. sedangkan formulir yang biasa digunakan untuk para pedagang kelontong adalah formulir 1770 hal ini menyebabkan adaptasi materi yang dilakukan oleh team pengabdi yang semula e-filling menjadi e-form. tahapan yang dilakukan adalah setelah login para peserta dapat langsung ke menu lapor kemudian memilih pelaporan jenis e-form, setelah masuk kemenu e-form terdapat menu formulir 1770 yang dapat didownload, ketika mendownload formulir ini secara langsung peserta akan mendapatkan email masuk nomor aktivasi yang nantinya dapat digunakan. formulir 1770 dapat diisi secara langsung yang mana tahapannya dimulai dari lembar keempat dan bertahap sampai lembar pertama, jika sudah selesai para peserta dapat melakukan submit atau secara singkat proses pelaporan spt tahunannya dapat digambarkan sebagai berikut: 


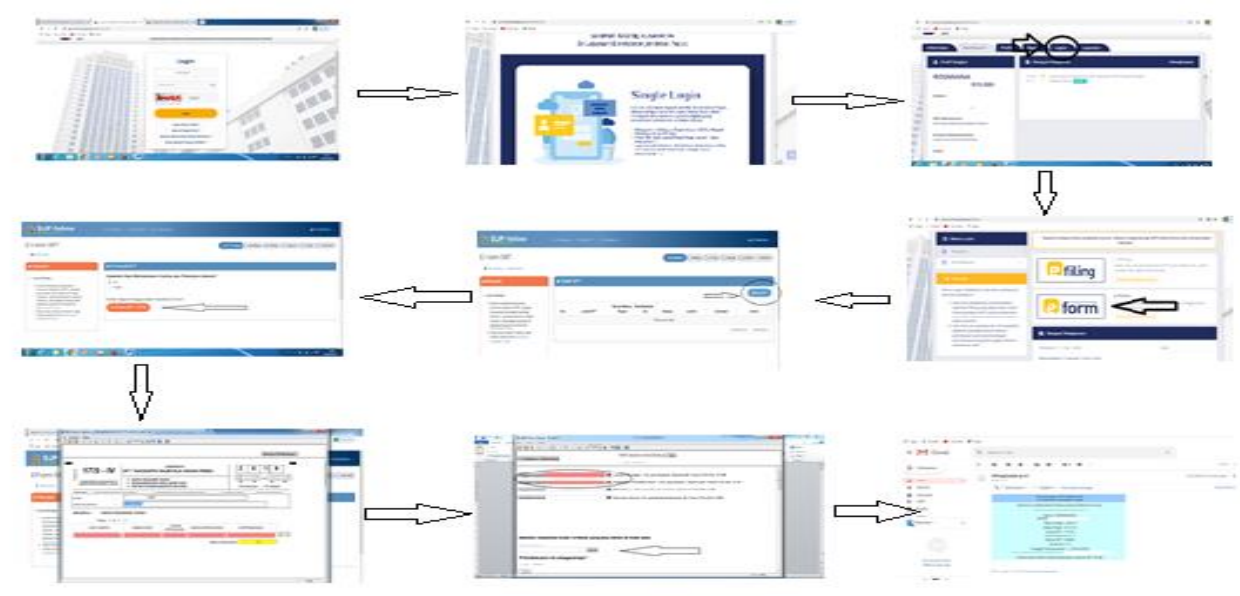

Gambar 1. Langkah-langkah pelaporan e-spt

\section{Antara Teori dan Praktek}

Secara teori untuk terdaftar sebagai Wajib Pajak e-Filing melalui website Direktorat Jenderal Pajak (djponline.pajak.go.id), Wajib Pajak yang sudah mendapatkan e-FIN harus mendaftarkan diri paling lama tiga puluh hari kalender sejak diterbitkannya e-FIN. Pendaftaran dilakukan melalui website Direktorat Jenderal Pajak (djponline.pajak.go.id) dengan mencantumkan : a) Alamat surat elektronik (email address); dan b) Nomor telepon genggam (handphone), c) Untuk pengiriman kode verifikasi dan notifikasi. Wajib Pajak yang telah terdaftar sebagai Wajib Pajak e-Filing melalui website Direktorat Jenderal Pajak (djponline.pajak.go.id) dapat menyampaikan SPT Tahunan dengan cara mengisi e-SPT dengan benar, lengkap dan jelas. Wajib Pajak yang telah mengisi eSPT harus meminta kode verifikasi pada website Direktorat Jenderal Pajak. Selanjutnya Wajib Pajak mendapatkan notifikasi setiap menyampaikan SPT Tahunan secara e-Filing melalui website Direktorat Jenderal Pajak (djponline.pajak.go.id). Dalam hal e-SPT dinyatakan lengkap oleh Direktorat Jenderal Pajak, kepada Wajib Pajak diberikan Bukti Penerimaan Elektronik sebagai tanda terima penyampaian SPT Tahunan. Dengan diberikannya kemudahan oleh DJP melalui e-Filing ini diharapkan dapat meningkatkan kepatuhan Wajib Pajak atas penyampaian Surat Pemberitahuan Tahunan Pajak Penghasilan Wajib Pajak baik orang pribadi maupun badan (Astuti, 2015).

Secara praktek, penerapan e-spt ini mengalami cukup banyak kendala dilapangan dimana salah satunya adalah diwajibkannya setiap wajib pajak untuk memiliki e-fin terlebih dahulu agar dapat login (masuk) kedalam menu e-filing pada website Direktorat Jenderal Pajak (djponline.pajak.go.id). Selain belum memiliki e-fin terdapat beberapa peserta yang ternyata belum memiliki email pribadi yang merupakan syarat mutlak agar dapat dikirimkan informasi baik itu kode verifikasi maupun surat penerimaan spt tahunan secara elektronik. penyesuaian-penyesuaian dilakukan dilapangan yang menyebabkan dari 20 (dua puluh) peserta yang terdaftar, hanya 10 (sepuluh) peserta saja yang berhasil didampingi sampai selesai pelaporan pajaknya, 4 (empat) peserta didampingi pelaporan secara manual sedangkan sisanya masih menunggu kebijakan dari pihak yang berwenang. 
Dikarenakan situasi saat ini yaitu dengan adanya virus corona (covid-19), permaklumanpermakluman diberikan oleh AR pajak, yang mana beberapa wajib pajak dapat memperoleh e-fin dengan tidak perlu datang ke kantor pajak, cukup mengirimkan NPWP, alamat email, foto ktp ke nomor whatsapp AR yang bertanggung jawab mendampingi masing-masing wajib pajak. proses ini membutuhkan waktu sampai seminggu mulai dari mengirim pesan sampai mendapat jawaban. namun proses ini tidak bisa diterapkan secara sama kesemua peserta dikarenakan terdapat peserta yang tidak mengetahui siapa AR nya ataupun tidak mendapatkan persetujuan dari AR yang berwenang sehingga mengharuskan wajib pajak tetap datang kekantor pajak.

\section{Kelebihan dan Kelemahan penerapan e-spt ditengah wabah covid-19}

Kelebihan pelaporan pajak dengan aplikasi e-spt bagi Wajib Pajak yaitu menjadikan pekerjaan Wajib Pajak lebih efisien karena dengan adanya e-spt, Wajib Pajak tidak perlu mengantri lama di KPP dan menghabiskan banyak kertas untuk keperluan melaporkan atau menyampaikan SPT Tahunannya. Cukup dengan menyampaikan secara online dan memberikan bukti penyampaian ke KPP proses penyampaian SPT selesai dilakukan, selain itu para wajib pajak bisa tetap berada dirumah untuk melaporkan SPT tahunannya hal ini secara tidak langsung telah membantu pemerintah dalam mengurangi penyebaran virus corona atau covid-19. Sedangkan bagi KPP Pratama Mataram, walapun tidak dapat bertemu langsung dengan wajib pajak namun dengan adanya pemberlakuan aplikasi e-spt akan memberikan pelayanan terbaik, perekaman data menjadi lebih cepat dan akurat, serta mengatasi masalah pada Seksi Pelayanan.

Kekurangan pada penerapan aplikasi e-spt yang dialami Wajib Pajak di antaranya adalah kurangnya pengetahuan masyarakat terhadap penggunaan teknologi sehingga cukup menghambat dalam penerapan, perlakuan social distancing yang diterapkan menyebabkan tidak optimalnya sosialisasi penerapan e-spt pada masyarakat sehingga masyarakat yang belum paham akan kewajiban dan kepatuhan wajib pajak khususnya bagi Wajib Pajak baru yang masih awam dengan penggunaan e-filing menjadi tidak dapat melaporkan SPT nya tahun ini, serta masalah jaringan internet yang menyebabkan proses transfer data ke server terkadang terhambat. Selain itu, Wajib Pajak yang menggunakan aplikasi e-Filing juga masih diwajibkan menyampaikan Induk SPT secara manual karena belum adanya aturan telematika tentang keabsahan tanda tangan digital.

\section{Kesimpulan}

Berdasarkan pembahasan diatas, adapat dilihat bahwasanya penerapan e-filing bagi masyarakat terbukti sangat memberatkan, mayoritas peserta pendampingan mengeluhkan kesulitan yang dialami, mulai dari kurangnya pengetahuan akan penggunaan komputer hingga harus memakai quota internet agar dapat melaporkan pajaknya. selain itu penggunaan e-filing tidak dapat digunakan oleh para pedagang kelontong dikarenakan formulir yang dipakai adalah 1770 sehingga saat pelaporan pajak beralih dari e-filing menjadi e-form. walaupun masih terdapat beberapa kendala namun penerapan e-spt dinilai mampu mengatasi permasalahan yang terjadi setelah diberlakukannya kebijakan social distancing sehingga para wajib pajak tidak harus datang kekantor pajak dan mengantri. 


\section{Pengakuan}

Kegiatan pengabdian ini tidak mungkin dapat terlaksana secara lancar tanpa dukungan dari berbagai pihak, untuk itu kami sebagai team pengabdi mengucapkan terima kasih kepada; pertama kepada perguruan tinggi Universitas Bumigora Khususnya fakultas ekonomi dan bisnis; kedua kepada Mitra yang bersedia untuk kami bimbing di tengah ketakutan akan wabah corona ini; ketiga AR pajak yang membimbing kami dalam membantu mitra dalam melakukan pelaporan pajak.

\section{Daftar Pustaka}

Abdurrohman, S., Domai, T., \& Shobaruddin, M. (2015). Implementasi Progam e-Filing dalam Upaya Peningkatan Kepatuhan Wajib Pajak Orang Pribadi (Studi pada Kantor Pelayanan Pajak Pratama Bojonegoro). JAP, 3(5), 807-811.

Andhika, Jaka. 2020. Dampak Pandemi Covid-19 Bagi Penyelenggara Pelayanan Publik, https://ombudsman.go.id/artikel/r/artikel--dampak-pandemi-covid-19-bagi-penyelenggaraanpelayanan-publik. diakses sabtu 30 mei 2020.

Astuti, Inne Nidya. 2015. Analisis Penerapan E-Filing Sebagai Upaya Meningkatkan Kepatuhan Wajib Pajak Dalam Penyampaian Surat Pemberitahuan (Spt) Tahunan Pada Kantor Pelayanan Pajak Pratama Gresik Utara. Jurnal Akuntansi. Universitas Negeri Surabaya. Vol 3 No. 3

onlinepajak. 2018. Apa yang Dimaksud dengan e-Filing?. https://www.online-pajak.com/apa-yangdimaksud-dengan-e-filing. diakses 19 februari 2020

Peraturan Direktur Jenderal Pajak Nomor : PER - 01/PJ/2014 tentang Tata Cara Penyampaian Surat Pemberitahuan Tahunan Bagi Wajib Pajak Orang Pribadi Menggunakan Formulir $1770 \mathrm{~S}$ atau 1770SS Secara e-Filing melalui website Direktorat Jenderaal Pajak (www.pajak.go.id). (Online)( http://www.ortax.org) Diakses pada tanggal 18 Desember 2019 


\section{ADMA}

Gurnal Pengabdian dan Pemberdayaan Masyarakat
Vol.1, No.1, June 2020, pp. 19-26

Doi: $x x x x x x x x$ 